\title{
Spider species richness and sampling effort at Cracraft'S Belém Area of Endemism
}

\author{
BRUNO V.B. RODRIGUES ${ }^{1}$, MANOEL B. AGUIAR-NETO ${ }^{2}$, UBIRAJARA DE OLIVEIRA ${ }^{3}$, ADALBERTO \\ J. SANTOS ${ }^{3}$, ANTONIO D. BRESCOVIT ${ }^{1}$, MARLÚCIA B. MARTÍNS ${ }^{2}$ and ALEXANDRE B. BONALDO ${ }^{2}$ \\ ${ }^{1}$ Instituto Butantan, Laboratório Especial de Coleções Zoológicas, Av. Vital Brasil, 1500, 05503-900 São Paulo, SP, Brazil \\ ${ }^{2}$ Museu Paraense Emílio Goeldi, Coordenação de Zoologia, Avenida Perimetral, \\ 1901, Caixa Postal 399, 66077-530 Belém, PA, Brazil \\ ${ }^{3}$ Universidade Federal de Minas Gerais, Instituto de Ciências Biológicas, Departamento de \\ Zoologia, Av. Antonio Carlos, 6627, 31270-901 Belo Horizonte, MG, Brazil
}

Manuscript received on June 19, 2015; accepted for publication on March 18, 2016

\begin{abstract}
A list of spider species is presented for the Belém Area of Endemism, the most threatened region in the Amazon Basin, comprising portions of eastern State of Pará and western State of Maranhão, Brazil. The data are based both on records from the taxonomic and biodiversity survey literature and on scientific collection databases. A total of 319 identified species were recorded, with 318 occurring in Pará and only 22 in Maranhão. About $80 \%$ of species are recorded at the vicinities of the city of Belém, indicating that sampling effort have been strongly biased. To identify potentially high-diversity areas, discounting the effect of variations in sampling effort, the residues of a linear regression between the number of records and number of species mapped in each $0.25^{\circ}$ grid cells were analyzed. One grid, representing the Alto Turiaçu Indigenous land, had the highest deviation from the expected from the linear regression, indicating high expected species richness. Several other grid cells showed intermediate values of the regression residuals, indicating species richness moderately above to the expected from the model.
\end{abstract}

Key words: Amazon, araneae, diversity, fragmentation.

\section{INTRODUCTION}

Spiders are both highly abundant and diverse organisms. There are above 46.000 species described (World Spider Catalog 2017), but these figure is presumed to represent only a fraction of the actual species diversity of the group (Costello et al. 2012). Additionally, the taxonomic and biogeographic knowledge on the spiders is biased both taxonomically and geographically (Brescovit

Correspondence to: Bruno Vinicius Bastos Rodrigues

E-mail: bruno.vbrodrigues@gmail.com et al. 2011a). The Amazon Basin in particular is still largely unknown regarding spider species richness and composition and the available samples from this region came mostly from easily accessible areas (Heyer et al. 1999, Oliveira 2011), as already observed for Amazonian plants (Nelson et al. 1990, Hopkins 2007) and birds (Vale and Jenkins 2012). Several spider inventories have been done in recent years in Brazilian Amazonia (Bonaldo et al. 2009a, b, Ricetti and Bonaldo 2008, Bonaldo and Dias 2010, Dias and Bonaldo 2012, Venticinque et al. 2007). However, despite these efforts, large 
portions of the Amazon Basin remain undersampled and the checklists provided were mostly based in the recognition of morphospecies, a situation that severely limits the study of biogeographic patterns.

The Amazon Basin presents high landscape heterogeneity, with several distinct phytophysiognomies that offer a myriad of different habitats (Silva et al. 2005). Studies on biogeography of vertebrates (Haffer 1978 [birds], Ávila-Pires 1995 [lizards], Silva and Oren 1996 [primates], Ron 2000 [amphibians]) indicated that the distribution of several species in the Amazon Basin is not continuous and proposed that the similar patterns of limited distribution of these vertebrates could lead to the recognition of areas of endemism. According to these authors, eight to ten areas of endemism can be delimited within the Amazon Basin. These areas of endemism are separated by the main river systems, which supposedly acted as effective physical barriers for these animals and lead to vicariant events of speciation (Haffer and Prance 2002 - but see Oliveira et al. 2015).

The Belém Area of endemism (BAE), proposed by Cracraft (1985) based on historical biogeography of avifauna, represent unique homogeneous ecoregion, originally covered by dense ombrophyllous Amazonian forest. This is the most threatened of the areas of endemism proposed by Cracraft (1985) for the Amazon Basin, suffering with habitat loss caused by deforestation, fire and fragmentation (Silva et al. 2005). In the last 400 years, the BAE has undergone great landscape transformations, being currently formed by a mosaic of forest remnants. Most of these remnants are covered by relatively young secondary forest, since nearly half the deforestation within the BAE occurred in the last 30 years. The primary forest remnants are restricted to a few large blocks, represented by indigenous reservations, the Gurupi Biological Reserve and a few private areas (Almeida and Vieira 2010). The BAE also comprises the northern portion of the "arc of deforestation", a large region stretching from the State of Maranhão to the State of Acre (Ferreira et al. 2005), which concentrates most of the logging and agricultural activities in the Brazilian Amazonia (Costa and Pires 2010).

As indicated above, the delimitation of Amazonian areas of endemism is based on vertebrate distribution data. The distribution of lesser-known taxonomic groups, like arthropods, is still virtually unknown for the entire Amazon basin, except for studies based on butterflies (Brown et al. 1995, Racheli and Racheli 2004). Considering that arthropods represent the majority of animal species on Earth, filling this knowledge gap seems to be an urgent task for the effective conservation of Amazonian biota. Thus, this study provides a faunistic list of spiders from the BAE, with data compiled from all available sources, including ordinary material from museum collections as well as data from primary taxonomic and biodiversity survey literature. Furthermore, we map the species richness and sampling effort of spiders in the BAE. We restrict the list to the specimens that were identified down to species, since non-identified morphospecies distribution could not be accessed in large geographic scale without examining primary specimens. Thus, the list represents only a portion of the sampling at hand, and is obviously just a fraction of the actual spider species richness in the area. Considering that the rate of success of species identification in structured inventories carried on in east Amazonia fluctuates between 25\% and 35\%, we estimate that the list below represents nearly $30 \%$ of all species of the BAE available in the studied collections. However, that small portion is the only one that is readily comparable to similar lists from other regions, reflecting the current knowledge on taxonomy of Amazonian spiders. Gathering these data progressively for each of the areas of endemism recognized for the Amazon basin could prove to be a necessary step towards 
understanding how spiders are distributed in the region.

\section{MATERIALS AND METHODS}

The BAE is totally inserted in Brazilian territory, located in the physiographic zone that lie on east of State of Pará and west of State of Maranhão, comprising $243.753,18 \mathrm{Km}^{2}$, located between $00^{\circ}$ $30^{\prime}$ and $06^{\circ} 00^{\prime} \mathrm{S}$ and $44^{\circ} 00^{\prime}$ ' and $50^{\circ} 00^{\prime} \mathrm{W}$ (Figure 1a). The BAE includes 27 conservation units and 14 indigenous lands in 149 municipalities, 69 of which in Pará and 80 in Maranhão (Almeida and Vieira 2010). The vegetation is composed mainly of Dense Ombrophyllous Forest and areas characterized by different types of use. It also has two main climate areas, the humid equatorial with annual average rainfall greater than $2.000 \mathrm{~mm}$, and the tropical equatorial zone with annual average rainfall of $1.500 \mathrm{~mm}$. The relief is composed by plateaus, depressions and plains (Almeida et al. 2013).

A list of spider species recorded in the BAE were compiled from the databases of Museu Paraense Emílio Goeldi (MPEG, curator: A.B. Bonaldo), Instituto Butantan, São Paulo (IBSP, curator: A.D. Brescovit) and Museu de Zoologia da Universidade de São Paulo (MZSP, curator: R. Pinto da Rocha). These collections were chosen because they hold greater representation of the BAE spider fauna. Records from the taxonomic and biodiversity survey literature were gathered from a database of Brazilian spider distribution (see Brescovit et al. 2011a). The list is arranged taxonomically as in the World Spider Catalog (2017).

To determine which species were considered potentially endemic, first we reviewed the primary literature of all species and we indentified which had distribution restricted to BAE. Then, we checked whether these species were present in other localities in the collection databases, and also verified the presence of these species in important species lists of the Neotropical region, especially in Amazon (Dias and Bonaldo 2012, Höfer and Brescovit 2001, Ricetti and Bonaldo 2008, Venticinque et al. 2008, Bonaldo et al. 2009a, b, Brescovit et al. 2011a, Buckup et al. 2010). Thus, a species was only considered potentially endemic if recorded so far only for the BAE, being absent in the verified databases and species list.

To access the current state of knowledge of spider species richness in the BAE, the number and density of distribution records were used as indicators of sampling effort. The spatial variation of the sampling effort and species richness was expressed in maps with $0.25^{\circ}$ grid cells. This size of grid cells was considered ideal because raster maps with larger grid cells would not reveal collecting gaps. Grid cells were classified regarding the number of records and species into five categories according to the natural gaps in their distribution, which ranks values in ranges with the greatest variation, calculated using DIVA-GIS (Hijmans et al. 2004) and ArcGIS 10.1 (ESRI 2012).

The relationship between species richness and sampling effort in the sampled area was analyzed through a least-squares linear regression. To identify potentially high-diversity areas, discounting the effect of variations in sampling effort, we analyzed the residues of the linear regression between the number of records and number of species in each grid cell. The potential diversity of each cell was expressed as the difference between the species richness observed and expected according to the regression model, composing an index of potential species richness, which were plotted on a map. All statistical analyses were done in Statistica 7.0 (StatSoft 2004).

\section{RESULTS AND DISCUSSION}

A total of 319 species distributed in 163 genera and 39 families were recorded for the BAE (Appendix 
- Supplemantary Material). These figures represent an underestimation, since much of the material in collections are from unrevised groups and was therefore not included. This taxonomic deficit is reflected even in the representation of families known to occur in the region: the number of families listed should be 46, but Anapidae, Caponiidae, Deinopidae, Dictynidae, Filistatidae, Mimetidae, Philodromidae and Symphytognathidae are recorded only from specimens identified, at best, to genus level. On the other hand, the families Araneidae (99 spp.), Salticidae (52 spp.) and Theridiidae (36 spp.) are the most representative, with about $60 \%$ of total identified species. It is not a coincidence that the majority of recent revisions of Neotropical genera are from these families, which are also the groups with more nominal species in the lists of states of São Paulo (Brescovit et al. 2011a) and Rio Grande do Sul (Buckup et al. 2010).

This paper records the occurrence of spiders in about $25 \%$ of the BAE municipalities, seven belonging to the state of Maranhão and thirty-one to the state of Pará (Table I). All listed species were recorded in Pará, except Micrathena macfarlanei Chickering, 1961. Only 22 species were recorded in Maranhão. This odd pattern may be explained by a differential sampling effort, much more intense in the state of Pará. The city of Belém, capital of the state of Pará, contributed with about $80 \%$ of all species recorded in the entire BAE (Figure 1b). The municipality of Belém was an important collecting point of XIX century naturalist expeditions to Brazil, and it was reported in old literature as "Le Para" (Levi 1964a). As a result, the BAE presents great historic significance to taxonomy, harboring the type localities of at least 40 spider species, all of them from state of Pará, 29 of which from Belém. Additionally, the fact that Belém presently harbors one of the most important Brazilian spider collections (MPEG) and an active spider taxonomy and ecology study group also explains this pattern. The contribution to the BAE spider samples for the list of the state of Pará as a whole is also very expressive. Brescovit et al. (2011a) recorded 3,203 nominal species from Brazil, in 659 genera and 72 families. From the state of Pará, there are 696 nominal species recorded, distributed in 291 genera and 46 families (Brescovit et al. 2011b). About $40 \%$ of these species are recorded in the BAE.

The linear regression model indicated a strong relationship between species richness and sampling effort, expressed by the number of records $\left(\mathrm{R}^{2}=0.96\right.$, $\mathrm{p}<0.01$ ) (Figure $1 \mathrm{~b}, \mathrm{c}$ ). The greatest concentration of sampling effort is in the northwestern BAE and, as mentioned above, the surroundings of the city of Belém is particularly diverse, with 247 species. The second more diverse region was the Alto Turiaçu Indigenous land, with 78 species. However, this region had the highest deviation from the expected from the linear regression model, indicating expected species richness highly above the observed. The relationship between the observed species richness and sampling effort in this grid was comparatively weak, and no recent records were obtained from that area (all records from the region were produced in a single locality - Canindé, municipality of Paragominas, in the state of Pará (2॰31'50”S 46 $\left.25^{\circ} 19^{\prime \prime} \mathrm{W}\right)$ - sampled in the 60 's by B. Malkin). Thus, the Paragominas vicinities may be elected as a priority area for further spider inventories within the BAE. Several grid cells showed intermediate values of the regression residuals, indicating a species richness moderately above the expected by the regression model (Figure 1d).

Due to the large sampling gaps across the Amazon Basin, which impose several limitations to the knowledge of actual distribution patterns of Amazonian spiders (Oliveira et al. 2015), as well as several taxonomic limitations, which prevent the input of data, determining species that may be endemic to a given region is not an easy task. The situation is further complicated by the scanty and poorly informative historical literature, as well as 
by the lack of experts who could provide reliable identifications. Nevertheless, it was possible to identify 18 species with potentially endemic distribution within the BAE (Table II). This figure probably do not represent the actual fauna of BAE endemics, since at least some groups that were reported in the literature to be microdistributed, as Oonopidae (Platnick et al. 2013, Bonaldo et al. 2014), were severely misrepresented in the present data set. However, many spider species present a wide distribution and some species are capable to occupy synanthropic habitats (e.g. Brazil et al. 2005). In the current study, 27 synanthropic species were recorded. The most common ones are

TABLE I

Total of identified spider species recorded in municipalities from the Belém Area of Endemism.

\begin{tabular}{|c|c|c|}
\hline State & Municipalities & $\begin{array}{c}\mathrm{N}^{\circ} \\
\text { Species }\end{array}$ \\
\hline Maranhão & Açailândia & 1 \\
\hline Maranhão & Bom Jardim & 7 \\
\hline Maranhão & Centro Novo do Maranhão & 16 \\
\hline Maranhão & Mirinzal & 2 \\
\hline Maranhão & Perí-Mirim & 1 \\
\hline Maranhão & Pindaré-Mirim & 2 \\
\hline Maranhão & São Bento & 2 \\
\hline Pará & Abaetetuba & 1 \\
\hline Pará & Acará & 2 \\
\hline Pará & Ananideua & 14 \\
\hline Pará & Barcarena & 8 \\
\hline Pará & Belém & 247 \\
\hline Pará & Benevides & 20 \\
\hline Pará & Bragança & 19 \\
\hline Pará & Breu Branco & 5 \\
\hline Pará & Bujarú & 4 \\
\hline Pará & Capanema & 1 \\
\hline Pará & Capitão-poço & 2 \\
\hline Pará & Castanhal & 2 \\
\hline
\end{tabular}

Hasarius adansoni (Audouin, 1826), Menemerus bivittatus (Dufour, 1831), Nesticodes rufipes (Lucas, 1846), Oecobius concinnus Simon, 1893, Plexippus paykulli (Audouin, 1826), Physocyclus globosus (Taczanowski, 1874) and Zosis geniculata (Olivier, 1789). Two species, Cithaeron praedonius O. Pickard-Cambridge, 1872 and Zimiris doriai Simon, 1882, were recently recorded for the first time in western Amazonian region (Ruiz and Bonaldo 2013).

The data here presented depicts the state of knowledge of spider taxonomy and the sampling effort applied so far in one of the most impacted areas of Brazilian Amazon, highlighting great sampling gaps in the area, especially in the Amazonian portions of the state of Maranhão, from

TABLE I (continuation)

\begin{tabular}{|c|c|c|}
\hline State & Municipalities & $\begin{array}{c}\mathrm{N}^{\circ} \\
\text { Species }\end{array}$ \\
\hline Pará & Dom Eliseu & 1 \\
\hline Pará & Goianésia do Pará & 1 \\
\hline Pará & Igarapé-Açu & 8 \\
\hline Pará & Irituía & 1 \\
\hline Pará & Jacundá & 11 \\
\hline Pará & Marapanim & 1 \\
\hline Pará & Marituba & 3 \\
\hline Pará & Mocajuba & 2 \\
\hline Pará & Moju & 16 \\
\hline Pará & Nova Ipixuna & 18 \\
\hline Pará & Paragominas & 76 \\
\hline Pará & Primavera & 1 \\
\hline Pará & Santa Bárbara & 4 \\
\hline Pará & Santa Isabel & 5 \\
\hline Pará & Santo Antônio do Tauá & 5 \\
\hline Pará & São Domingos do Capim & 1 \\
\hline Pará & Tailândia & 21 \\
\hline Pará & Tomé-Açú & 2 \\
\hline Pará & Vigia & 2 \\
\hline
\end{tabular}



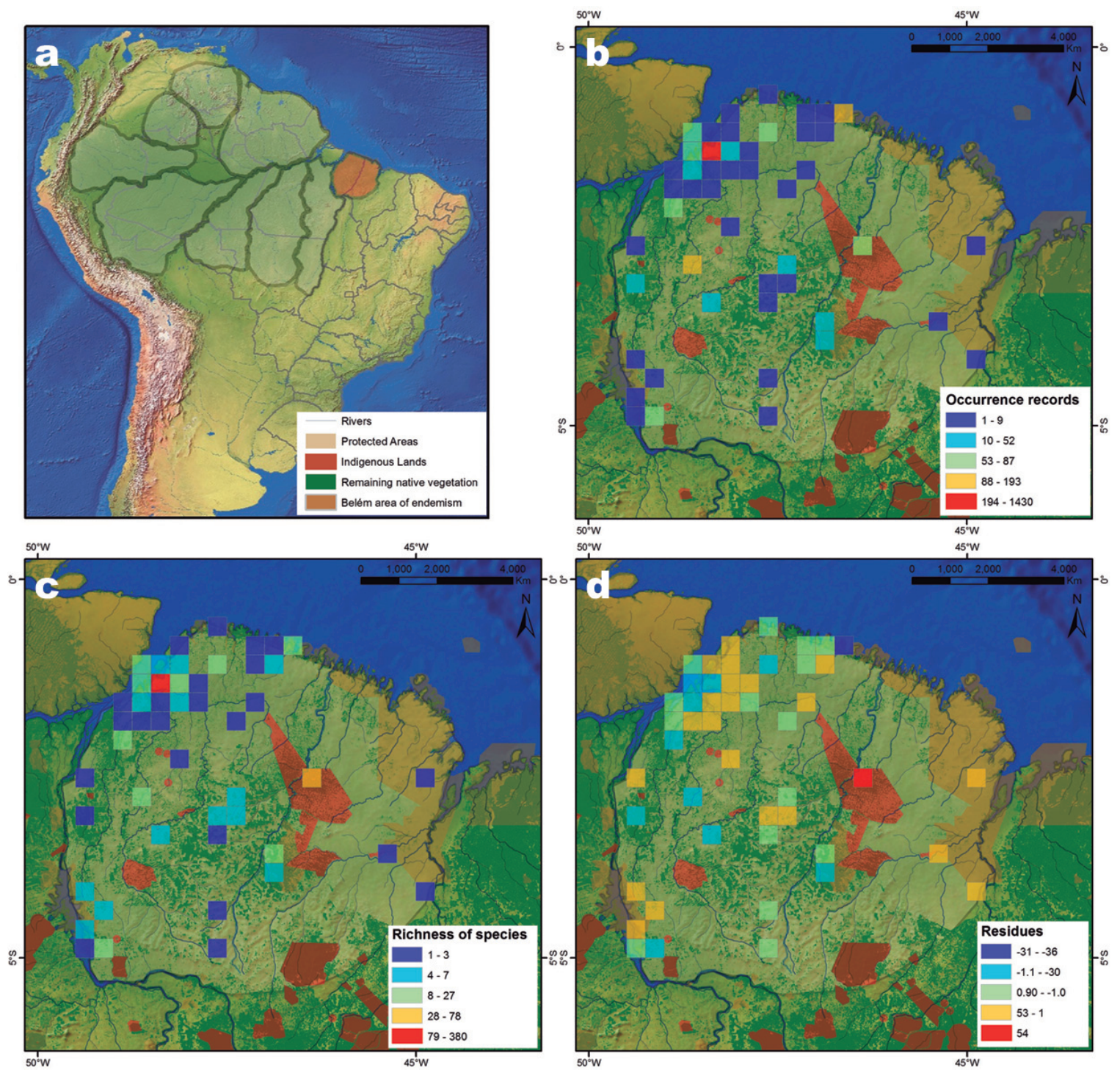

Figure 1 - a, Localization of the Belém Area of Endemism; b, number of distribution records per grid cell; c, observed species richness and, $\mathbf{d}$, residues from species richness $\mathrm{X}$ distribution records linear regression (see text for details).

where only 22 species were recorded. We expect that replicating the present approach to other areas in the Amazon Basin can contribute to a better understanding of the patterns of spider distribution in the region. Addressing the question to how congruent are these patterns with those presented by other groups could ultimately lead to a refinement of the current recognized areas of endemism.

The preservation of forest remnants has been an increasingly important concern, since the fragmentation compromises the natural populations, resulting in the disappearance of species even before they are known to science. For this reason, some areas should be considered priority for structured inventories. In the BAE region, the central Dense Ombrophyllous Forest remnants would be the most important, since they still have continuous patches of primary forest. These areas have the greater potential species richness values, but are largely undersampled regarding spider fauna, presenting few records of either identified or unidentified individuals. Some of these remnants are small (less 
TABLE II

Potentially endemic species of spiders from the Belém Area of Endemism.

\begin{tabular}{|c|c|}
\hline Family & Potentially endemic species \\
\hline Araneidae & Metazygia aldela Levi, 1995 \\
\hline Araneidae & Taczanowskia trilobata Simon, 1897 \\
\hline Corinnidae & Abapeba echinus (Simon, 1896) \\
\hline Idiopidae & Idiops siolii (Bücherl, 1953) \\
\hline Linyphiidae & Paraletes timidus Millidge, 1991 \\
\hline Oonopidae & Aschnaoonops caninde Platnick et al., 2013 \\
\hline Oonopidae & Aschnaoonops belem Platnick et al., 2013 \\
\hline Oonopidae & Scaphiella capim Platnick \& Dupérré, 2010 \\
\hline Palpimanidae & Otiothops baculus Platnick, 1975 \\
\hline Palpimanidae & Otiothops facis Platnick, 1975 \\
\hline Salticidae & Freya rubiginosa (C. L. Koch, 1846) \\
\hline Salticidae & Lyssomanes sylvicola Galiano, 1980 \\
\hline Senoculidae & Senoculus plumosus (Simon, 1880) \\
\hline Theridiidae & $\begin{array}{l}\text { Rhomphaea velhaensis (González \& } \\
\text { Carmen, 1996) }\end{array}$ \\
\hline Theridiidae & Theridion agrarium Levi, 1963 \\
\hline Theridiidae & Theridion paraense Levi, 1963 \\
\hline Thomisidae & Titidius gurupi Esmerio \& Lise, 1996 \\
\hline Thomisidae & Tobias epicadoides Mello-Leitão, 1944 \\
\hline
\end{tabular}

than 15 ha) and largely surrounded by pastures or other human-modified landscapes, a situation that makes them particularly vulnerable to habitat destruction. Furthermore, the surroundings of these remnants also depicts small patches of poorly sampled primary forest that also deserve attention, a situation that makes the central portion of BAE to be considered the top priority for the conducting future spider inventories within the region.

\section{ACKNOWLEDGMENTS}

This paper is a contribution of the Project "Instituto Nacional de Ciência e Tecnologia em Biodiversidae e Uso da Terra na Amazônia" (INCT - CNPq Proc.: 574008-2008-0). Field and laboratory work was also sponsored by the Programa de
Pesquisa em Biodiversidade (PPBio/NLP, CNPq Grant 558202/2009-8). The support from various grants was greatly appreciated: Coordenação de Aperfeiçoamento de Pessoal de Nível Superior (CAPES), Conselho Nacional de Desenvolvimento Científico e Tecnológico (CNPq), Fundação de Amparo à Pesquisa do Estado de Minas Gerais (FAPEMIG) and Fundação de Amparo à Pesquisa do Estado de São Paulo (FAPESP). ABB, CNPqPQ grant \#304965/2012-0; ADB, CNPq-PQ grant \#301776/2004-0 and FAPESP 2011/50689-0; AJS, CNPq grants \#475179/2012-9 and \#308072/20120 . AJS also thanks FAPEMIG (PPM-0033513), CNPq (475179/2012-9, 407288/2013-9, 308072/2012-0) and Instituto Nacional de Ciência e Tecnologia dos Hymenoptera Parasitóides da Região Sudeste Brasileira (http:/www.hympar. ufscar.br/). BVBR received a Doctoral fellowship (CAPES). UO was sponsored by FAPEMIG and CAPES fellowships.

\section{REFERENCES}

ALMEIDA AS AND VIEIRA IMC. 2010. Centro de Endemismo Belém: Status da Vegetação Remanescente e Desafios para a Conservação da Biodiversidade e Restauração Ecológica. REU (Sorocaba) 36: 95-111.

ALMEIDA AS, VIEIRA ICG AND ROCHA DPN. 2013. Relatório Executivo: Projeto: cenários para a Amazônia: uso da terra, biodiversidade e clima: subprojeto: caracterização e mapeamento dos padrões de uso e cobertura da terra no centro de endemismo Belém, Belém: Mus Para Emílio Goeldi, p. 11-14.

ÁVILA-PIRES TCS. 1995. Lizards of Brazilian Amazonia (Reptilia: Squamata). Zool Verh 299: 1-706.

BEATTY J. 1970. The spider genus Ariadna in the Americas (Araneae, Dysderidae). Bull Mus Comp Zool Harv 139: 433-518.

BERTANI R. 2012. Revision, cladistic analysis and biogeography of Typhochlaena C. L. Koch, 1859, Pachistopelma Pocock, 1901 and Iridopelma Pocock, 1901 (Araneae, Theraphosidae, Aviculariinae). ZooKeys 230: 1-94.

BONALDO AB. 1994. A subfamília Eutichurinae na região neotropical, com a revisão do gênero Eutichurus Simon, 1896 (Araneae, Miturgidae). Iheringia, Sér Zool 76: 101159. 
BONALDO AB. 2000. Taxonomia da subfamília Corinninae (Araneae, Corinnidae) nas regiões Neotropica e Neárctica. Iheringia, Sér Zool 89: 3-148.

BONALDO AB AND BRESCOVIT AD. 1994. Revision of the Neotropical spider genus Stethorrhagus (Araneae, Corinnidae). Andrias 13: 33-64.

BONALDO AB, BRESCOVIT AD, HOFER H, GASNIER T AND LISE AA. 2009a. A Araneofauna (Arachnida, Araneae) da Reserva Florestal Adolfo Ducke, Manaus, Amazonas, Brasil. In: Chilson EF and Magalhães C (Eds), A Fauna de Artrópodos da Reserva Florestal Adolpho Ducke. Estado Atual do Conhecimento Taxonômico e Biológico, Manaus: Instituto Nacional de Pesquisa da Amazônia, Manaus, p. 201-222.

BONALDO AB ET AL. 2009b. Inventário e história natural dos aracnídeos da Floresta Nacional de Caxiuanã. In: Lisboa P (Ed), Caxiuanã: desafios para a conservação de uma Floresta Nacional na Amazônia, Belém: Museu Paraense Emílio Goeldi, Belém, p. 577-621.

BONALDO AB AND DIAS SC. 2010. A structured inventory of spiders (Arachnida, Araneae) in natural and artificial forest gaps at Porto Urucu, Western Brazilian Amazonia. Acta Amaz 40(2): 357-372.

BONALDO AB, RUIZ GRS, BRESCOVIT AD, SANTOS AJ AND OTT R. 2014. Simlops, a new genus of goblin spiders (Araneae, Oonopidae) from northern South America. Bull Am Mus Nat Hist 388: 1-60.

BRAZIL TK, ALMEIDA-SILVA LM, PINTO-LEITE CM, LIRA-DA-SILVA RM, PERES MCL AND BRESCOVIT AD. 2005. Aranhas sinantrópicas em três bairros da cidade de Salvador, Bahia, Brasil (Arachnida, Araneae). Biota Neotrop 5(1): 163-169.

BRESCOVIT AD. 1999. Revisão das aranhas do gênero Lupettiana Brescovit (Araneae, Anyphaenidae, Anyphaeninae). Rev Bras Zool 16(2): 63-76.

BRESCOVIT AD, OLIVEIRA U AND SANTOS AJ. 2011a. Aranhas (Araneae, Arachnida) do Estado de São Paulo, Brasil: diversidade, esforço amostral e estado do conhecimento. Biota Neotrop 11(1a): 1-32.

BRESCOVIT AD AND RHEIMS CA. 2000. On the synanthropic species of the genus Scytodes Latreille (Araneae, Scytodidae) of Brazil, with synonymies and records of these species in other Neotropical countries. Bull Br Arachnol Soc 11: 320-330.

BRESCOVIT AD, SANTOS AJ, RODRIGUES BVB, OLIVEIRA U AND BONALDO AB. 2011b. Censo da Biodiversidade. Belém: Museu Paraense Emílio Goeldi. Disponível em http://marte.museu-goeldi.br/ biodiversidade/censo/aplicacao/aranhas.php (Última data de acesso: 15/2/2016).

BROWN KS, KLITZKE CF, BERLINGERI C AND DOS SANTOS PER. 1995. Neotropical swallowtails: chemistry of food plant relationships, population ecology, and biosystematics. In: Scriber JM, Tsubaki Y and Lederhouse RC (Eds), Swallowtail butterflies: their ecology and evolutionary biology, Gainesville: Scientific Publishers, Gainesville, p. 405-445.

BUCKUP EH, MARQUES MAL, RODRIGUES ENL AND OTT R. 2010. Lista das espécies de aranhas (Arachnida, Araneae) do estado do Rio Grande do Sul, Brasil. Iheringia, Sér Zool 100: 483-518.

CARICO JE AND SILVA ELC. 2010. Taxonomic review of the Neotropical spider genus Paradossenus (Araneae: Lycosoidea: Trechaleidae: Trechaleinae) with a new erection of the subfamily Trechaleinae and a key to included genera. J Arachnol 38: 212-236.

COSTA MH AND PIRES GF. 2010. Effects of Amazon and Central Brazil deforestation scenarios on the duration of the dry season in the arc of deforestation. Int J Climatol 30(13): 1970-1979.

COSTELlO MJ, WILSON S AND HOULDING B. 2012. Predicting Total Global Species Richness Using Rates of Species Description and Estimates of Taxonomic Effort. Syst Biol 61: 871-883.

CRACRAFT J. 1985. Historical biogeography and patterns of differentiation within the South American avifauna: areas of endemism. In: Buckley PA et al. (Eds), Neotropical Ornithology, Ornithological Monographs $n^{\circ}$. 36, Washington: American Ornithologists Union, Washington, DC, p. 49-84.

DIAS SC AND BONALDO AB. 2012. Abundância relativa e riqueza de espécies de aranhas (Arachnida, Araneae) em clareiras originadas da exploração de petróleo na bacia do rio Urucu (Coari, Amazonas, Brasil). Bol Mus Para Emílio Goeldi, Sér Ciências Naturais 7(2): 123-152.

ESMERIO ME AND LISE AA. 1996. Revisão taxonômica do gênero Titidius Simon, 1895 da região neotropical (Araneae, Thomisidae, Thomisinae). Biociências 3: 185222.

ESRI. 2012. ArcGIS Desktop: Release 10.1. Redlands, CA. Environmental Systems Research Institute.

FERREIRA LV, VENTICINQUE E AND ALMEIDA S. 2005. O desmatamento na Amazônia e a importância das áreas protegidas. Estud Av 19(53): 157-166.

GALIANO ME. 1967. Salticidae (Araneae) formiciformes. VIII. Nuevas descripciones. Physis B Aires (C) 27: 27-39.

GALIANO ME. 1971a. Salticidae (Araneae) formiciformes. X. Revision del género Fluda Peckham, 1892. Physis B Aires (C) 30: 573-599.

GALIANO ME. 1971b. Salticidae (Araneae) formiciformes. XII. Descripcion del allotypus de Synemosyna paraensis Galiano, 1967. Rev Soc Entomol Argent 33: 133-135.

GALIANO ME. 1972. Revisión del género Chirothecia Taczanowski, 1878 (Araneae, Salticidae). Rev Mus Argent Cienc Nat (Ent.) 4: 1-42. 
GALIANO ME. 1974. Salticidae (Araneae) formiciformes. XIV. Descripción de dos nuevas espécies del gênero Myrmarachne MacLeay, 1839. Physis B Aires (C) 33: 221-230.

GALIANO ME. 1975. Salticidae (Araneae) formiciformes. XV. Descripción de Corcovetella aemulatrix, género y especie nuevos. Physis B Aires (C) 34: 33-39.

GALIANO ME. 1979a. Revision del género Frigga C. L. Koch, 1851 (Araneae, Salticidae). Acta Zool Lilloana 33: 113-135.

GALIANO ME. 1979b. Revision of the genus Phiale C. L. Koch, 1846 (Araneae, Salticidae). II. Phiale guttata (C. L. Koch, 1846) new combination. Bull Br Arachnol Soc 4: 345-348.

GALIANO ME. 1980. Revisión del género Lyssomanes Hentz, 1845 (Araneae, Salticidae). Op lilloana 30: 1-104.

GALIANO ME. 1981. Revision del genero Phiale C. L. Koch, 1846 (Araneae, Salticidae) III. Las especies polimorficas del grupo mimica. J Arachnol 9: 61-85.

GALIANO ME. 1982. Revision del genero Nycerella (Araneae, Salticidae). Physis B Aires (C) 41: 53-63.

GALIANO ME. 1986. Salticidae (Araneae) formiciformes. XVI. Especies nuevas o poco conocidas de Simprulla, Fluda, Descanso y Peckhamia. Physis B Aires 44: 129139.

GALIANO ME. 1994. Revision of the genus Pachomius (Araneae, Salticidae). Bull Br Arachnol Soc 9: 214-220.

GALIANO ME. 1996. Formiciform Salticidae (Araneae). Two new combinations and four new species of the genera Martella and Sarinda. Misc Zool 19: 105-115.

GALIANO ME. 1998. Revision of the genus Chinoscopus (Araneae, Salticidae, Lyssomanidae). Bull Br Arachnol Soc 11: 1-9.

GALIANO ME. 2001. Revisión de las especies de Freya del grupo decorata (Araneae, Salticidae). J Arachnol 29: 2141.

GERTSCH WJ. 1967. The spider genus Loxosceles in South America (Araneae, Scytodidae). Bull Am Mus Nat Hist 136: 117-174.

GLUECK S. 1994. A taxonomic revision of the orb weaver genus Acacesia (Araneae: Araneidae). Psyche J Entom 101: 59-84.

GONZÁLEZAAND CARMEN DC. 1996. Neotropical spiders of the genus Argyrodes Simon (Araneae, Theridiidae). Bull Br arachnol Soc 10: 127-137.

HAFFER J. 1978. Distribution of Amazon forest birds. Bonner Zool Beitr 29: 38-78.

HAFFER J AND PRANCE GT. 2002. Impulsos climáticos da evolução na Amazônia durante o Cenozóico: sobre a teoria dos Refúgios da diferenciação biótica. Estud Av 16: $175-206$
HEYER WR ET AL. 1999. Amazonian biotic data and conservation decisions. Ciência e Cultura. J Braz Assoc Adv Sci 51: 372-385.

HIJMANS RJ, GUARINO L, BUSSINK C, MATHUR P, CRUZ M, BARRANTES I AND ROJAS E. 2004. DIVAGIS, version 4. A geographic information system for the analysis of biodiversity data. Manual. (Available at http:// www.diva-gis.org).

HÖFER H AND BRESCOVIT AD. 2001. Species and guild structure of a Neotropical spider assemblage (Araneae) from Reserva Ducke, Amazonas, Brazil. Andrias 15: 99119.

HOPKINS MJG. 2007. Modelling the known and unknown plant biodiversity of the Amazon Basin. J Biogeogr 34: 1400-1411.

HUBER BA. 2000. New World pholcid spiders (Araneae: Pholcidae): A revision at generic level. Bull Mus Comp Zool Harv 254: 1-348.

JOCQUÉ R. 1988. An updating of the genus Leprolochus (Araneae: Zodariidae). Stud Neotrop Fauna E 23: 77-87.

LEVI HW. 1963a. American spiders of the genus Theridion (Araneae, Theridiidae). Bull Mus Comp Zool Harv 129: 481-589.

LEVI HW. 1963b. American spiders of the genera Audifia, Euryopis and Dipoena (Araneae: Theridiidae). Bull Mus Comp Zool Harv 129: 121-185.

LEVI HW. 1963c. The American spider genera Spintharus and Thwaitesia. Psyche J Entom 70: 223-234.

LEVI HW. 1964a. Nineteenth century South American araneology. Papéis Dep Zool S Paulo 16: 9-19.

LEVI HW. 1964b. American spiders of the genus Episinus (Araneae: Theridiidae). Bull Mus Comp Zool Harv 131: $1-25$.

LEVI HW. 1964c. American spiders of the genus Phoroncidia (Araneae: Theridiidae). Bull Mus Comp Zool Harv 131: 65-86.

LEVI HW. 1985. The spiny orb-weaver genera Micrathena and Chaetacis (Araneae: Araneidae). Bull Mus Comp Zool Harv 150: 429-618.

LEVI HW. 1986. The Neotropical orb-weaver genera Chrysometa and Homalometa (Araneae: Tetragnathidae). Bull Mus Comp Zool Harv 151: 91-215

LEVI HW. 1988. The neotropical orb-weaving spiders of the genus Alpaida (Araneae: Araneidae). Bull Mus Comp Zool Harv 151: 365-487.

LEVI HW. 1989. The Neotropical orb-weaver genera Epeiroides, Bertrana and Amazonepeira (Araneae: Araneidae). Psyche J Entom 96: 75-99.

LEVI HW. 1991a. The Neotropical and Mexican species of the orb-weaver genera Araneus, Dubiepeira, and Aculepeira (Araneae: Araneidae). Bull Mus Comp Zool Harv 152: 167-315. 
LEVI HW. 1991b. The Neotropical orb-weaver genera Edricus and Wagneriana (Araneae: Araneidae). Bull Mus Comp Zool Harv 152: 363-415.

LEVI HW. 1992a. Spiders of the orb-weaver genus Parawixia in America (Araneae: Araneidae). Bull Mus Comp Zool Harv 153: 1-46.

LEVI HW. 1992b. The American species of the orb-weaver genus Carepalxis and the new genus Rubrepeira (Araneae: Araneidae). Psyche J Entom 98: 251-264.

LEVI HW. 1993. The Neotropical orb-weaving spiders of the genera Wixia, Pozonia, and Ocrepeira (Araneae: Araneidae). Bull Mus Comp Zool Harv 153: 47-141.

LEVI HW. 1995a. The Neotropical orb-weaver genus Metazygia (Araneae: Araneidae). Bull Mus Comp Zool Harv 154: 63-151.

LEVI HW. 1995b. Orb-weaving spiders Actinosoma, Spilasma, Micrepeira, Pronous, and four new genera (Araneae: Araneidae). Bull Mus Comp Zool Harv 154: 153-213.

LEVI HW. 1996a. The American orb weavers Hypognatha, Encyosaccus, Xylethrus, Gasteracantha, and Enacrosoma (Araneae, Araneidae). Bull Mus Comp Zool Harv 155: 89-157.

LEVI HW. 1996b. The genus Taczanowskia of the orb-weaver spider family Araneidae (Araneae). An Inst Biol Univ Mex (Zool.) 67: 183-195.

LEVI HW. 1999. The Neotropical and Mexican Orb Weavers of the genera Cyclosa and Allocyclosa (Araneae: Araneidae). Bull Mus Comp Zool Harv 155: 299-379.

LEVI HW. 2007. The orb weaver genus Mangora in South America (Araneae, Araneidae). Bull Mus Comp Zool Harv 159: 1-144.

MELLO-LEITÃO CF. 1944. Algumas aranhas da região amazônica. Bolm Mus Nac Rio de J (Zool.) 25: 1-12.

MILLIDGE AF. 1991. Further linyphiid spiders (Araneae) from South America. Bull Mus Comp Zool Harv 205: 1-199.

NELSON BW, FERREIRA CAC, DA SILVA MF AND KAWASAKI ML. 1990. Refugia, endemism centres and collecting density in Brazilian Amazonia. Nature 345: 714-716.

OLIVEIRA U. 2011. Diversidade e Biogeografia de Aranhas do Brasil: Esforço Amostral, Riqueza Potencial e Áreas de Endemismo. Dissertação de Mestado, Universidade Federal de Minas Gerais, Minas Gerais. (Unpublished). Available: http://www.bibliotecadigital.ufmg.br/dspace/ handle/1843/BUOS-8MYHSA.

OLIVEIRA U, BRESCOVIT AD AND SANTOS AJ. 2015. Delimiting Areas of Endemism through Kernel Interpolation. PLoS ONE 10(1): 1-18.

PLATNICK NI. 1975. A revision of the palpimanid spiders of the new subfamily Otiothopinae (Araneae, Palpimanidae). Am Mus Novit 2562: 1-32.
PLATNICK NI AND BERNIKER L. 2013. The soft-bodied goblin spiders of the new genus Noonops (Araneae, Oonopidae). Am Mus Novit 3776: 1-48.

PLATNICK NI AND DUPÉRRÉ N. 2009. The goblin spider genera Opopaea and Epectris (Araneae, Oonopidae) in the New World. Am Mus Novit 3649: 1-43.

PLATNICK NI, DUPÉRRÉ N, BERNIKER L AND BONALDO AB. 2013. The goblin spider genera Prodysderina, Aschnaoonops, and Bidysderina (Araneae, Oonopidae). Bull Am Mus Nat Hist 373: 1-102.

RACHELI L AND RACHELI T. 2004. Patterns of Amazonian area relationships based on raw distributions of papilionid butterflies (Lepidoptera: Papilioninae). Biol J Linnean Soc 82(3): 345-357.

RHEIMS CA. 2007. Revision of the Neotropical spider genus Macrinus (Araneae, Sparassidae). J Arachnol 35: 159-170.

RHEIMS CA AND BRESCOVIT AD. 2006. Spiders of the genus Scytodes Latreille (Araneae: Scytodidae) from Brazilian cerrado and caatinga. Bull Br Arachnol Soc 13: 297-308.

RICETTI J AND BONALDO AB. 2008. Diversidade e estimativas de riqueza de aranhas em quatro fitofisionomias na Serra do Cachimbo, Pará, Brasil. Iheringia, Sér Zool 98(1): 88-99.

RON SR. 2000. Biogeographic area relationships of lowland Neotropical rainforest based on raw distributions of vertebrate groups. Biol J Linnean Soc 71: 379-402.

RUIZ GRS AND BONALDO AB. 2013. Vagabond but elusive: two newcomers to the Eastern Amazon (Araneae: Cithaeronidae; Prodidomidae). Zootaxa 3694: 92-96.

SANTOS AJ. 2007a. A revision of the Neotropical nurseryweb spider genus Architis (Araneae: Pisauridae). Zootaxa 1578: 1-40.

SANTOS AJ. 2007b. A phylogenetic analysis of the nurseryweb spider family Pisauridae, with emphasis on the genera Architis and Staberius (Araneae: Lycosoidea). Zool Scr 36(5): 489-507.

SANTOS AJ AND NOGUEIRAAA. 2008. Three new species, new records and notes on the nursery-web spider genus Architis in Brazil (Araneae: Pisauridae). Zootaxa 1815: 51-61.

SCHMIDT G. 1993. Vogelspinnen: Vorkommen, Lebensweise, Haltung und Zucht, mit Bestimmungsschlüsseln für alle Gattungen, Vierte Auflage. Landbuch Verlag, Hannover, $151 \mathrm{p}$.

SCIOSCIA CL. 1997. Revisión del género Parnaenus Peckham y Peckham, 1896 (Araneae, Salticidae). Physis B Aires 53: 37-47.

SILVA JMC AND OREN DC. 1996. Application of parsimony analysis of endemicity in Amazonian biogeography: an example with primates. Biol J Linnean Soc 39: 427-437. 
SILVA JM, RYLANDS AB AND FONSECA GAB. 2005. O destino das áreas de endemismo na Amazônia. Megadiversidade 1(1): 124-131.

SIMON E. 1900. Descriptions d'arachnides nouveaux de la famille des Attidae. Ann Soc Entomol Bel 44: 381-407.

STATSOFT. 2004. Statistica: data analysis software system: version 7.0 .

TRAW MB. 1996. A revision of the Neotropical orb-weaving spider genus Scoloderus (Araneae: Araneidae). Psyche 102: 49-72.

VALE M AND JENKINS C. 2012. Across-taxa incongruence in patterns of collecting bias. J Biogeogr 39: 1744-1748.

VENTICINQUE EM, REGO FNA, BRESCOVIT AD, RHEIMS CA AND RUIZ GRS. 2008. A Araneofauna (Arachnida, Araneae) das várzeas do Rio Amazonas:
Padrões de distribuição e estado do conhecimento atual. In: Albernaz ALKM (Ed), Conservação da várzea: identificação e caracterização de regiões biogeográficas, Manaus. Ibama/ProVárzea, Manaus, p. 179-198.

WORLD SPIDER CATALOG. 2017. Natural History Museum Bern, online at http://wsc.nmbe.ch, version 16 (date of last access: 04/07/2017).

\section{SUPPLEMENTARY MATERIAL}

Appendix - List of spider species recorded in the Belém Area of Endemism, with their respective data sources, municipalities and type-localities (when within the BAE). *Potentially endemic species; ${ }^{*}$ Synantropics species. 